Wendy D. Manning Bowling Green State University

Pamela J. Smock* University of Michigan

\title{
"Swapping" Families: Serial Parenting and Economic Support for Children
}

The claim that fathers "swap" families when they form new ones-that is, they shift allegiances from nonresident children to new residential children (e.g., Furstenberg, 1995)—has not been directly evaluated empirically. Drawing on data from the two waves of the National Survey of Families and Households, we test Furstenberg's argument in terms of child-support transfers to nonresidential children, and we also test an elaboration of his approach that distinguishes between resident biological children and stepchildren. Using staticscore models, our findings indicate that fathers do swap families but only when the trade-off is between new biological children living inside fathers' households and existing biological children living outside fathers' households. Even though our analytic sample is small, our findings have important implications for child well-being, childsupport policy, and the meaning of fatherhood.

From the perspective of children, families are increasingly likely to be spread across more than one household, with one biological parent, typically the father, living in a separate household. In

Department of Sociology, Bowling Green State University, Bowling Green, OH 43403 (wmannin@opie.bgsu.edu).

*Department of Sociology and Population Studies Center, University of Michigan, Ann Arbor, MI 48104.

Key Words: child support, divorce, fatherhood, nonresident parenting.
1990, at least 22 million children-over one third of all children-in the United States did not live with their biological fathers, and about half of all children are expected to live in a single-parent family at some point before adulthood (Bumpass \& Sweet, 1989a; Norton \& Miller, 1992). At the same time, many fathers enter new unions, often acquiring new biological children or stepchildren (Sorensen, 1997).

These patterns raise a general question critical to understanding both the well-being of children and the meaning of fatherhood in the United States: Do fathers reduce their social and economic investments in children from whom they live apart as they take on new parenting roles? In this paper, we focus on the economic dimension of this question. Our aim is to test a notion suggested by Furstenberg and colleagues that nonresident fathers "swap" families (e.g., Furstenberg, 1995; Furstenberg \& Cherlin, 1991; Furstenberg, Nord, Peterson, \& Zill, 1983; Furstenberg \& Spanier, 1984). Specifically, we examine whether fathers reduce their child-support payments to nonresidential children when they have new children. We also elaborate Furstenberg's theory by developing and testing a hypothesis that distinguishes between new biological children and stepchildren.

Our focus on child support is important because social science research has shown that nonresidential father involvement benefits children, and particularly that child-support payments from nonresidential fathers positively affect children's outcomes above and beyond dollars from other 
sources (King, 1994; Knox \& Bane, 1994; McLanahan, Seltzer, Hanson, \& Thomson, 1994). Additionally, policy makers have recently focused on child-support reform as a foundation for improving the outcomes of children in the United States. Understanding the impact of fathers' new family responsibilities is essential for this effort.

\section{BACKGROUND}

Patterns of father disengagement from nonresidential biological children and the formation of new families have been described in terms of "swapping" families (e.g., Furstenberg \& Nord, 1985; Furstenberg \& Spanier, 1984). The notion is that fathers trade old parenting responsibilities for new, with fatherhood being a transient state in which parental obligations are dictated by residence (Furstenberg, 1988, 1995; Furstenberg \& Cherlin, 1991; Seltzer, 1991). The underlying idea is that nonresident fathers face new demands when forming new families, leading them to withdraw their ties to nonresident children and to base their economic and noneconomic investments within their current households (Ihinger-Tallman \& Pasley, 1987). Furstenberg and Cherlin (1991, p. 37) state, "When fathers invest in new family responsibilities, such as having additional children, the offspring from their first marriage sometimes get the short shrift." A part of this process may include showing allegiance to a new wife or partner as well as new children.

Trading allegiances from old children to new can be conceptualized in at least two ways. Defined in terms of social involvement, the swapping hypothesis has in fact received some support; past research indicates that children are unlikely to have both a biological father and stepfather socially involved in their lives on a regular basis (Furstenberg, 1988; Mott, 1990; Seltzer \& Bianchi, 1988). Direct empirical evidence to corroborate Furstenberg's theory in terms of the economic dimension of nonresidential parenting is lacking. However, Furstenberg's hypothesis is commonly regarded as true for all domains of father involvement, including economic support. Given the association between children's economic well-being, part of which is determined by child support, and children's life chances, this issue deserves scrutiny.

Most child-support studies that take into account fathers' new family responsibilities have relied on a rough proxy of fathers' new parenting responsibilities: fathers' new marriages (Furstenberg, 1988; Peters, Argys, Maccoby, \& Mnookin, 1993; Seltzer,
1991; Sonenstein \& Calhoun, 1992; Teachman, 1991; exceptions include Hill, 1992; Veum, 1993). This is problematic for at least two reasons. First, researchers have sometimes, because of data limitations, used mothers' reports of fathers' new marriages (McLanahan et al., 1994; Seltzer, 1991; Teachman, 1991). However, mothers are not always reliable sources of information about fathers' lives. Seltzer and Brandreth (1994), for example, find significant differences in resident mothers' and nonresident fathers' reports of fathers' remarriages. More important, remarriage is not an adequate measure of new parenting responsibilities because it does not distinguish the formation of new unions from raising new children. To test Furstenberg's hypothesis, the needed measure is one that focuses on children within and across households rather than on ties to an adult via remarriage.

Two approaches have been applied to examine nonresident fathers' financial disengagement. One approach uses mothers' reports of child-support levels paid at specific years since separation. This work suggests that, as time since separation increases, the levels of child support paid decline (Seltzer, 1991; Teachman, 1991). However, this work can only be considered suggestive, because the aggregate comparisons do not permit analysis of individual fathers' changes in child support paid. As a result, this type of analysis cannot assess the factors associated with changes in child support paid. The second approach uses longitudinal data to examine changes in child support paid by nonresident fathers. A study using relatively young nonresident fathers (28-31 years old) from the National Longitudinal Survey of Youth (Veum, 1993) and another study, based on married couples from the original 1968 sample of the Panel Study of Income Dynamics (PSID) (Hill, 1992), include coresident children primarily as a control variable and do not explicitly test the swapping hypothesis. These studies suggest that coresident children do not influence changes in child support paid, but they do not account for the biological relationship of these children to the nonresident parent.

\section{HYPOTHESES}

Our first hypothesis is drawn from Furstenberg's premise that fathers trade parenting responsibilities, withdrawing from nonresidential children when they acquire new, coresidential children. As Furstenberg et al. (1983) state, "Social parenthood takes precedence over biological parenthood" (p. 666). 
Hypothesis 1: The addition of new resident children (i.e., either biological children or stepchildren) lowers economic investments in nonresidential, biological children.

We operationalize "economic investments" as child support payments in our analyses because it is the primary means by which nonresident parents transfer income to their children. The emotional and financial responsibilities resulting from residing with children may interfere with fathers' possible relationships with their nonresidential biological children. Nonresident fathers with new families may perceive competing responsibilities and loyalties across households (Clingempeel, Coylar, \& Hetherington, 1994; Ihinger-Tallman \& Pasley, 1987). It also may be easier and less stressful from a father's perspective to provide for children who are sharing a residence with him than to do so for children living in other households. Providing economic support often requires contact with the child's mother, sometimes causing strains that a father may wish to avoid (Adritti \& Kelly, 1994; Ahrons, 1993; Arendell, 1995; Seltzer, McLanahan, \& Hanson, 1998). Economic theory also supports this hypothesis. Whereas fathers can be certain that all of their economic investments in resident children are received by the children, only a portion of the payment to mothers for nonresident children may be received by the children themselves. Thus, as fathers may face reduced incentives to pay child support (Weiss \& Willis, 1985), they may choose to invest in resident children and not in nonresident children.

Hypothesis 1 does not distinguish between new biological children and stepchildren, reflecting Furstenberg's contention that coresidence is the critical element determining fathers' investments. In our second hypothesis, we refine Furstenberg's theory by distinguishing between new biological children and stepchildren. Conceptual arguments from economics, evolutionary biology, and sociology imply that nonresident fathers only raising stepchildren will not swap family responsibilities; the trade-off is between supporting biological children living inside and those outside their household.

Economist Gary Becker (1981), for example, suggests that there is an important distinction between stepchildren and biological children. He argues that men invest more heavily in "maritalspecific capital" - one type of which is biological children with a new wife or partner-than in children from a previous union. Because stepchildren do not represent marital-specific capital according to Becker, the implication is that their presence will not influence fathers' economic contributions to biological children living elsewhere.

Evolutionary biologists take a different approach, but their argument leads to similar conclusions. Trivers (1974) suggests that a conflict of interest arises between parents and biological offspring when investment in one child limits investment in future children. In response to such a situation, fathers may divert resources from older offspring to younger offspring when older offspring appear capable of surviving without their fathers' resources. In the human context, one signal of capacity to survive might simply be that a child lives with the mother and experiences a moderate level of well-being. This argument does not apply to stepchildren; it is only when the future offspring are biological children that the trade-off occurs.

Finally, family sociologists argue that stepfamilies are "incomplete institutions," an arrangement in which the roles (i.e., rights and obligations) of family members are not clearly defined (Cherlin, 1978), especially as compared to first marriages with only biological children. This implies that fathers might not respond to the presence of stepchildren in their decision-making about contributions to nonresidential children. The following empirical evidence supports the distinction between stepchildren and biological children. Fathers' parenting of children differs depending on the biological relationship to them (Marsiglio, 1992): stepchildren are more often excluded from fathers' lists of family constituents than are biological children (Furstenberg \& Cherlin, 1991), and nonresident fathers living only with biological children report more benefits from parenthood than nonresidential fathers living with stepchildren (Seltzer \& Brandreth, 1994).

Hypothesis 2: Only new biological children lower fathers' economic investments in nonresidential, biological children; new residential stepchildren have no effect on fathers' economic investments in nonresidential, biological children.

This hypothesis argues for separate effects in a particular direction and is essentially an elaboration of Hypothesis 1, not an alternative to it. For example, the empirical results could support both Hypothesis 1 and 2. This would suggest that, in general, the mechanism driving the relationship between coresident children and child-support payments is coresident biological children, indi- 
cating the need for a substantive refinement of Furstenberg's theory. This would also be the case, of course, if Hypothesis 2 is supported but Hypothesis 1 is not, which would imply that collapsing different kinds of new children into one category obscures differential effects of new biological and stepchildren.

\section{MethoD}

\section{Data}

The National Survey of Families and Households (NSFH) is a national probability sample of approximately 13,000 individuals. The first wave (NSFH1) was conducted between 1987 and 1988. The second wave (NSFH2) reinterviewed respondents and was conducted between 1992 and 1994. The response rate for the first wave of the NSFH was $74 \%$, and the follow-up response rate was roughly $82 \%$ of the original sample (Sweet, Bumpass, \& Call, 1989).

An important advantage of the NSFH is that it directly asks respondents whether they have children living outside the household. Other data sources require indirect identification of nonresidential fathers (e.g., Survey of Income and Program Participation) or do not attempt to gather information from nonresident fathers (e.g., Current Population Survey). Another asset of the $\mathrm{NSFH}$ is that we can infer causality because the two waves of data collection allow us to conduct dynamic analyses that link changes in child-support payments over time to changes in coresident children. The NSFH is also suited to this project because it contains rich data on many aspects of family experiences, such as legal support arrangements, income, residential histories, and marriage and cohabitation histories.

The eligible sample was based on male main respondents, who reported having an absent "focal" biological child less than 13 years old residing with his or her mother and who provided complete child support information $(n=298)$ in the first wave. Ten percent of the sample was limited because of missing child-support data. A focal child was randomly selected among all absent children less than age 18, and child-support questions referred to a focal child (and his or her coresident siblings), not to all sets of nonresidential children. Because we focused on changes in childsupport payments across the waves, we also restricted the sample to children less than age 13 at the first wave, so that they remain eligible for child support at the second wave. Fathers, in many cases, did not owe support or pay for other expenses when children reached age 18 .

Our final analytical sample was restricted to those fathers who met the above criteria and who were also reinterviewed at the second wave; remained nonresidential fathers of the same focal, absent child at both waves; reported that the child continued to live with his or her mother; and provided data on the amount of child support paid at Wave 2. Of the 298 eligible nonresidential fathers, 213 were reinterviewed. Next, the sample was reduced to 170 to assure that the focal child remained the same at both waves. A different focal child was sometimes referenced in the second wave, and there was no systematic reason for this change. The sample was further limited to 155 cases in which the focal child continued to live with his or her mother at Wave 2. We use this criterion because child-support obligations change if children move in with their fathers, other relatives, or foster parents. Our last criterion was that complete child-support information was provided.

The resulting sample contains 133 cases or only about $45 \%$ of the cross-sectional sample. This may be problematic for two reasons. The first is small sample size. Although unfortunate, we believe that the importance of the research aims, combined with the strength of the dynamic analyses, outweigh reservations about sample size. Our small sample size will lower the statistical power of our estimates. Another potential problem is clearly sample selectivity. Fathers in our sample may differ in unmeasured ways from those that did not meet all criteria. If this is so, parameter estimates of effects may be biased (Heckman, 1979). We address this problem in two ways. The first is simply by comparing the distributions of independent variables of those cases that meet all our criteria with those that do not. Second, we estimate a sample selection model that jointly predicts falling into our final sample and child support. By allowing the error terms of the two equations to be correlated, this model attempts to adjust coefficients for potential observed sample selectivity.

A final limitation of our sample and data is one that plagues virtually all studies of nonresident fathers. Fathers may either not be reporting all of their absent children (Cherlin, Griffith, \& McCarthy, 1983; Seltzer \& Brandreth, 1994) or not participating in the survey at all. Unfortunately, without the use of administrative records, it is difficult to assess the accuracy of fathers' reports of nonresident children. The likely direction of the bias is that the nonresident fathers identified in our study 
have lived with their children, probably representing fathers with closer economic and social ties to their children than the population of nonresident fathers as a whole (Lin \& Schaeffer, 1995; Schaeffer, Seltzer, \& Kalwitter, 1991). Both underrepresentation of nonresident fathers and underreporting of their children remain unresolved problems for research on fathers, and our selection models do not account for these unobserved biases.

\section{Measures}

The dependent variable in our multivariate analyses is the logged monthly amount of child support reported paid by the nonresidential father at Wave 2. The measure includes payments to the focal child and to his or her coresident siblings. Some research suggests that nonresident fathers and resident mothers report similar levels of child support (Seltzer \& Brandreth, 1994; Smock \& Manning, 1997), and fathers' own reports of child support paid are important to consider. Our measure of child support captures both formal and informal payments. Including both types is important because some fathers make payments to nonresidential children without a child-support order, or they pay more than the order (Seltzer, 1994). We control for child support paid at Wave 1 (measured in a similar manner to the Wave 2 variable), resulting in analyses that predict change in child support paid. The child-support amounts are adjusted by the Consumer Price Index to represent constant 1994 dollars.

To operationalize our hypotheses, our key independent variables concern new coresident children. We construct the following variables: (a) number of new coresident children; (b) number of new coresident biological children (i.e., births between interviews); and (c) number of new stepchildren acquired between interviews. A model containing the first variable tests Hypothesis 1, and a model containing the latter two, in lieu of the first, tests Hypothesis 2. To test the second hypothesis, we also include a control variable measuring the number of biological children who move into a father's household between the two waves; these are not the "new" children implicit in the swapping hypothesis, but they need to be taken into account.

Our other control variables are drawn from past theory and research. Almost all are measured as of the first wave of the survey and include characteristics of the father and the focal child. The only variable available in the first wave about the mother was the father's proxy report of her current marital status; we have excluded this information because of missing data and low expected reliability (see Seltzer \& Brandreth, 1994). Sociodemographic and economic characteristics of the father include age, race, current union status, educational attainment, and earnings. We measure age of the father in years and anticipate that older fathers have the economic resources to pay their child support (Zill, 1996). Race is categorized broadly into White and nonwhite because of sample size limitations. Prior work suggests that nonwhite fathers are less likely to pay child support than white fathers, partly because of differences by race in the prevalence of nonmarital births (Sorensen, 1997). The relationship between remarriage and child support varies in prior work (e.g., Seltzer, 1991). Current union status is coded " 1 " if the father is either married or cohabiting at Wave 1. We include both union types, because a substantial minority of individuals, especially among those who have been previously married, enter cohabitations rather than remarriages (e.g., Bumpass \& Sweet, 1989b). We code educational attainment as a series of four dummy variables. Studies indicate that fathers' education is positively associated with child-support payments (Braver, Fitzpatrick, \& Bay, 1991; Veum, 1993). A father's economic situation is captured with his earnings and is coded by dividing earnings by 10,000 . Prior work indicates that earnings are positively associated with child-support levels (Braver et al., 1991; Hill, 1992; Smock \& Manning, 1997; Teachman 1991). We include a squared term for earnings to test whether the variable earnings has a nonlinear effect.

We also measure other aspects of fathers' lives that have been found to be related to child support. We include a dummy variable indicating whether the father reports having a legal childsupport agreement. Legal agreements are associated with higher child-support payments (Seltzer, 1991). We also incorporate a measure of whether the father ever lived with the focal child, because residence with the child may create stronger ties to the child and thus be associated with higher levels of payments (Seltzer, 1991). Finally, we include a measure of the years since the father and child last coresided. Past research indicates that longer durations since coresidence have a negative impact on levels of child support payments (Seltzer, 1991). Fathers who never lived with their child are assigned the value of the age of the child.

The focal child variables include age, sex, dis- 
tance from the father's current residence, and the number of coresident siblings of the focal child. Older children have been found to be more likely to receive payments than younger children (Furstenberg \& Harris, 1992; Seltzer, 1991). Age of the focal child is coded in years. We include the gender of the focal child as well, although past research yields mixed results about the effects of this variable (Furstenberg et al., 1983; Paasch \& Teachman, 1993; Seltzer, 1991; Seltzer \& Bianchi, 1988). Distance between the child's and father's residences is coded as a continuous variable in miles. Previous research indicates that the greater the physical distance, the lower the likelihood of financial payments (Seltzer, 1991; Sonenstein \& Calhoun, 1990). We include the squared value of distance to test whether distance has a nonlinear effect. Finally, we include a measure of the number of full siblings less than age 18 living in the focal child's household. This is an important variable because the number of siblings will be related to the amount of child support owed by the father. Generally, the greater the number of children, the larger the child-support obligation. We include number of siblings at both Wave 1 and Wave 2 to allow us to control for child-support obligations at both interview waves.

\section{Analysis}

We conduct multivariate analyses using maximumlikelihood tobit models to analyze changes in child support. We use tobits rather than ordinary least squares, because the dependent variable is quite skewed, due to a substantial proportion of fathers who report that they pay no child support. Tobit estimation assumes that independent variables have both linear and nonlinear effects and produces consistent estimates of coefficients and standard errors. We employ static-score models to predict changes in child-support payments across the two waves (Finkel, 1995; Kessler \& Greenberg, 1981). The static-score model includes a lagged endogenous version of the dependent variable. In the current application, the lagged variable is the logged monthly child support paid at Wave 1 .

Because of the possible selectivity of our sample, we estimate a sample selection model to account for observed selection. It jointly estimates two equations: a probit predicting whether a case is included in our sample and a tobit model predicting change in child support. The probit equation uses all potentially eligible cases $(n=298)$ and predicts cases included in our sample $(n=$
133). The correlation between the equations shows the direction and magnitude of nonrandom associations between sample status and changes in child support. If a model that assumes the correlation is zero fits the data well, then our singleequation estimates are unbiased. We estimate the model using maximum likelihood in HOTZTRAN (R. Avery \& J. Hotz, unpublished data).

Our analytic strategy is as follows. We estimate models to test each of the two hypotheses. The first model in each case is a baseline model that only includes increases in coresident children, along with important controls (child support paid at Wave 1, number of coresident children at Wave 1 , and number of the focal child's siblings at both waves). Given our sample size constraints, we then determine whether each of the control variables separately contributes to the fit of the model. We assess the goodness of fit by conducting loglikelihood ratio tests. To test the first hypothesis, we evaluate whether increases in the overall number of coresident children reduce child support payments. A negative and significant coefficient for the increase in coresident children would be consistent with the notion that fathers swap families. To test the second hypothesis, we distinguish between coresident stepchildren and biological children, evaluating whether increases in stepchildren or biological children reduce child support. If the coefficient for increase in stepchildren is insignificant and the coefficient for increase in new biological children is significant and negative, then we accept Hypothesis 2.

\section{RESULTS}

\section{Descriptive Statistics}

Table 1 shows that two fifths of nonresidential fathers coreside with other children at Wave 2, indicating that a substantial percentage of nonresidential fathers are potentially economically responsible for at least two households. Nearly one quarter are residing with two or more children. The next column shows that three tenths of nonresident fathers are coresiding with biological children, and the final column indicates that $15 \%$ are coresiding with stepchildren. Further analysis confirms that remarriage is a poor proxy for nonresident fathers' family responsibilities. Approximately two fifths $(41 \%)$ of men living in unions at Wave 2 (39\% in formal marriages and $48 \%$ in informal unions) are not coresiding with any children, whereas $7 \%$ of nonresidential fathers not in 
TABle 1. Nonresident Fathers' Parenting RESPONSIBILITIES

\begin{tabular}{|c|c|c|c|}
\hline & \multicolumn{3}{|c|}{ Coresident Children (\%) } \\
\hline & Total & Biological & Step \\
\hline \multicolumn{4}{|c|}{ Number at Wave 2} \\
\hline 0 & 60.0 & 69.8 & 84.2 \\
\hline 1 & 17.0 & 14.9 & 8.5 \\
\hline \multirow[t]{2}{*}{$2+$} & 23.0 & 15.3 & 7.3 \\
\hline & 100.0 & 100.0 & 100.0 \\
\hline \multicolumn{4}{|c|}{ Number of new coresident children between waves } \\
\hline 0 & 68.5 & 78.8 & 89.5 \\
\hline 1 & 20.1 & 14.0 & 5.6 \\
\hline \multirow[t]{2}{*}{$2+$} & 11.4 & 7.2 & 4.8 \\
\hline & 100.0 & 100.0 & 100.0 \\
\hline
\end{tabular}

Note: Weighted percentages and unweighted $n$ 's $(n=$ 133).

Source: National Survey of Families and Households, Waves 1 and 2 .

unions are raising a child in their household (results not shown).

Table 1 also shows the percentage of nonresident fathers who at Wave 2 are residing with new children (i.e., men who are living with children at Wave 2 with whom they were not living at Wave 1). A considerable share of men coreside with new children at Wave 2; almost one third $(31.5 \%)$ of nonresident fathers live with new coresident children at Wave 2, and the majority live with only one additional child. The next column shows that nearly one quarter $(22 \%)$ of nonresident fathers coreside with new biological children at Wave 2, and the final column indicates that one tenth are coresiding with new stepchildren.

On average, about three quarters of nonresidential fathers in our sample report paying at least some child support at Wave 1 and at Wave 2 (Table 2). This percentage is somewhat higher than that reported from other data sources, such as Survey of Income and Program Participation (SIPP) (Sorensen, 1997) and PSID (Smock \& Manning, 1997), but similar to other work using the NSFH (Meyer, 1998; Seltzer \& Brandreth, 1994). The mean monthly payment of child support at Wave 1 was $\$ 235$ (in 1994 dollars), and the median payment was $\$ 166$ per month. The mean amount of child support reported paid at Wave 2 (\$276) is slightly higher than at Wave 1. These numbers are also quite consistent with those based on mothers' reports from the U.S. Census Bureau (1993). In 1991, mothers with a support order who received any child support received on average $\$ 3,011$ per year. A comparable sample from our data is based on nonresident fathers at Wave 1 who have legal sup-
Table 2. Net Changes in Monthly Child Support PAID BETWEEN WAVES

\begin{tabular}{lcc}
\hline Change & $\begin{array}{c}\text { Proportion of All } \\
\text { Fathers }(\%)\end{array}$ & Mean Change \\
\hline Decrease & 40.1 & $\$ 174.17$ \\
No Change & 15.2 & $\$ 0.00$ \\
Increase & 44.6 & $\$ 248.46$ \\
$\quad$ Total & 100.0 & $\$ 40.70$ \\
\hline
\end{tabular}

Note: At Wave 1, 75.0\% of fathers paid child support, with a mean monthly amount paid of $\$ 235.46$; at Wave 2, $77.2 \%$ of fathers paid, with a mean monthly amount of $\$ 276.21$. All amounts are converted to 1994 dollars, and weighted values are reported. $n=133$.

Source: National Survey of Families and Households, Waves 1 and 2 .

port agreements and make some child support payments; fathers in this group report paying on average \$3,066 per year (in 1991 dollars).

Table 2 also shows changes in payments by nonresident fathers across interviews. Changes in amounts paid can be the result of changing childsupport obligations (e.g., changes in the number of children owed support) or changing decisions by fathers about how much they would like to pay. The vast majority of fathers $(85 \%)$ shifted their monthly child support payments, with slightly greater percentages increasing than decreasing their child-support payments. Overall, the average changes in child support paid were positive, with an increase of $\$ 41$ per month (results not shown). The average decline in payments was lower than the average gain in child-support payments between the interviews. If we limit changes to what may be considered substantial (plus or minus $\$ 50$ per month), then we find that one quarter (27\%) of nonresidential fathers paid at least $\$ 50$ less per month at Wave 2 than at Wave 1, and 38\% of nonresidential fathers paid at least $\$ 50$ more at Wave 2 than at Wave 1 (results not shown). The fathers who did not alter their payments were those who paid nothing at both interview waves. It is notable that a considerable share of fathers continued to support their children and often increased the level of payments. The increases appear to stem largely from "other support," which may in part reflect responses to increased financial needs of children in their adolescent years. If child-support payments alone are considered, the increases are much more modest.

Table 3 displays descriptive statistics for the variables used in our multivariate analyses. The first few rows provide information about the core independent variables. The mean increase in cores- 
TABle 3. Distribution of IndePendent Variables

\begin{tabular}{|c|c|}
\hline Variable & Value \\
\hline \multicolumn{2}{|l|}{ Number of new coresident children (mean) } \\
\hline All children & 0.52 \\
\hline Biological children: births & 0.29 \\
\hline Biological children: move in & 0.06 \\
\hline Stepchildren & 0.19 \\
\hline \multicolumn{2}{|l|}{ Wave 1 number of coresident children (mean) } \\
\hline All children & 0.54 \\
\hline Biological children & 0.30 \\
\hline Stepchildren & 0.25 \\
\hline $\begin{array}{l}\text { Child support paid at Wave } 1 \\
\text { (mean, in } 1994 \text { dollars) }\end{array}$ & $\$ 235.46$ \\
\hline \multicolumn{2}{|l|}{ Father's characteristics } \\
\hline $\begin{array}{l}\text { Age (mean) } \\
\text { Race }(\%)\end{array}$ & 32.5 \\
\hline Nonwhite & 27.9 \\
\hline White & 72.1 \\
\hline \multicolumn{2}{|l|}{ Union Status $(\%)$} \\
\hline Not in union & 51.6 \\
\hline Cohabit/married & 48.4 \\
\hline \multicolumn{2}{|l|}{ Education $(\%)$} \\
\hline$<12$ years & 19.0 \\
\hline 12 years & 45.0 \\
\hline $13-15$ years & 24.7 \\
\hline $16+$ years & 14.9 \\
\hline Earnings (mean, in 1994 dollars) & $\$ 20,217$ \\
\hline \multicolumn{2}{|l|}{ Ever lived with child (\%) } \\
\hline No & 28.1 \\
\hline Yes & 71.9 \\
\hline \multicolumn{2}{|l|}{ Legal agreement $(\%)$} \\
\hline No & 27.4 \\
\hline Yes & 72.6 \\
\hline Years since separation (mean) & 4.5 \\
\hline \multicolumn{2}{|l|}{ Child's characteristics } \\
\hline Age (mean) & 6.6 \\
\hline \multicolumn{2}{|l|}{ Gender $(\%)$} \\
\hline Female & 56.4 \\
\hline Male & 43.6 \\
\hline $\begin{array}{l}\text { Distance from father (mean, in } \\
\text { increments of } 100 \text { miles) }\end{array}$ & 5.51 \\
\hline $\begin{array}{l}\text { Number of full siblings in focal child's } \\
\text { residence, Wave } 1 \text { (mean) }\end{array}$ & 0.6 \\
\hline $\begin{array}{l}\text { Number of full siblings in focal child's } \\
\text { residence, Wave } 2 \text { (mean) }\end{array}$ & 0.2 \\
\hline
\end{tabular}

Note: Weighted percentages and unweighted $n$ 's $(n=$ 133).

Source: National Survey of Families and Households, Waves 1 and 2.

ident children is .52, and most of this is due to new biological children. The mean increase of biological children who move into their fathers' households between the waves is quite small (.06). The mean number of coresident children at Wave 1 is .54 , and the mean values for biological children and for stepchildren are .30 and .25 , respectively.

Fathers are on average 32 years old, and $72 \%$ of them are white. Almost half of them are living in a union at Wave 1 (30\% in marital and 18\% in cohabiting unions). The majority of fathers have at least 12 years of education, with only about $20 \%$ having less than 12 years of education. Mean earnings are $\$ 20,217$ per year. Also, the majority of fathers $(72 \%)$ lived with the focal child at some point and report having a legal child support agreement $(73 \%)$. The mean number of years since separation from the child is 4.5 years. The average amount of child support the fathers report paying per month at Wave 1 is $\$ 235$.

Regarding the focal child, mean age at Wave 1 is almost 7 years, and slightly over half of the focal children are female. The focal child and father live on average 551 miles from one another, although the median is a much lower 20 miles. The mean number of additional children the father supports in the focal child's household (i.e., full siblings of the focal child) decreases as siblings age out of their status as minors.

\section{Multivariate Results}

Table 4 shows results from the static-score models. The table presents two models: the first model tests Hypothesis 1 (Model 1), and a second model tests Hypothesis 2 (Model 2). The coefficients are tobit estimates of the effects of variables on the logged monthly payments to nonresidential children made at the second wave of the survey. The only control variable that contributes to the fit of our model is distance between residences of the nonresident father and his child.

The results for Model 1 indicate that new coresident children generally do not affect changes in child-support payments. The coefficient measuring the number of new children is statistically insignificant. Not surprisingly, even when we include all of the control variables, the effects of number of new children are about the same (results not shown). As expected, the amount of child support paid at Wave 1 has a statistically significant, positive effect on child support paid at Wave 2 , but the number of coresident children at Wave 1 and nonresident children at Wave 2 does not significantly influence levels of child support paid at Wave 2. Our findings lead us to reject Hypothesis 1: New resident children do not lower economic investments in nonresidential children. 
Table 4. Tobit Estimates of Change in Resident Children on Monthly Child Support Paid at Wave 2

\begin{tabular}{lcc}
\hline Variable & Model 1 & Model 2 \\
\hline Number of new coresident children & & \\
Coresident children & -0.34 & $-0.89^{* * * *}$ \\
Biological children: births & & 0.29 \\
Biological children: move in & & \\
Stepchildren & & \\
Wave 1 number of coresident children & -0.28 & -0.26 \\
Coresident children & & -0.25 \\
Biological children & & $0.73^{* * *}$ \\
Stepchildren & $-0.04 * *$ \\
Child support paid Wave 1 & & $-0.03^{* *}$ \\
Distance from father (in increments of 100 miles) & -0.16 & \\
Number of siblings & 0.64 & -0.19 \\
Wave 1 & -263.1 & 0.67 \\
Wave 2 & & -261.1 \\
Log likelihood &
\end{tabular}

$* p<.10 .{ }^{* *} p \leq .05 . * * * p \leq .01$

Source: National Survey of Families and Households, Waves 1 and 2. $n=133$.

Model 2 distinguishes between biological children and stepchildren. The coefficient for the number of additional biological children across the waves is negative and statistically significant at the .01 level. Nonresident fathers who had new children between the interview waves paid significantly less child support than those who experienced no change in the number of coresident biological children. The coefficient for the increase in stepchildren, on the other hand, does not approach statistical significance. Introducing each control variable separately does not increase the fit of the model; one important exception is distance between the nonresident father's and the child's residence. Distance does statistically contribute to the fit of the model at the $p=.10$ level; fathers living farther away pay less support than fathers who live closer. In any case, whether we include each control variable separately or the full array of control variables together, our initial pattern of findings does not change. Based on this evidence, we accept Hypothesis 2: The addition of children reduces child support to nonresidential children only when the new children are biological children.

Finally, we find little evidence of observed sample selectivity. First, the distributions of variables are fairly similar across samples (data not shown). The final analytical sample has a significantly greater percentage of female focal children, White nonresident fathers, and fathers with legal childsupport agreements than the percentage of fathers who were excluded from the sample. The sample selection model results indicate no evidence of se- lectivity, conditional on observed characteristics (Appendix Table 1). The rho representing the correlation between the error terms of the two equations is statistically insignificant, and a model restricting the correlation to be zero fits the data as well as the unrestricted model $(p=1.00)$. Also, the effects of the independent variables maintain similar levels of significance and magnitude.

\section{DISCUSSION}

In part as a response to changes in family patterns over recent years, the issue of fatherhood and its meaning has become a focus of much theoretical and empirical attention from social scientists. Our paper addresses a question with critical implications for these issues. We evaluate Frank Furstenberg's notion that fathers swap old children for new and whether social parenthood, defined by coresidence, takes precedence over biological parenthood. We focus on the economic dimension of allegiances to nonresidential children, namely child support. We conclude that Furstenberg is right, with one caveat: Fathers do "swap" families, but only when the trade-off is between new biological children living inside versus existing biological children living outside the fathers' households. Fathers do not appear to actually swap children, because on average, they continue to financially support nonresident children. These results are inconsistent with the notion that social parenthood, at least as defined by coresidence, takes general precedence over biological parenthood. Instead, biological par- 
enthood, when combined with coresidence, appears to take precedence. However, we must interpret these results somewhat tentatively because of our limited sample size.

An important potential concern is that our findings could be an artifact of official modifications in child-support orders due to fathers' new family responsibilities. We do not believe that this is the case. First, the majority of states have no guidelines that take into account "subsequent" families, and only 13 states have mandatory guidelines of this sort (Takas, 1991). Second, there is wide variation in the application of the guidelines (Office of Child Support Enforcement [OCSE], 1996). Third, and most important, empirical findings show that only a small proportion of award modifications are in fact due to changes in nonresidential fathers' family situations (OCSE, 1996).

Our contribution to policy dialogues about child support is that fathers appear to be adjusting their child support payments, probably often informally, to accommodate the demands of new biological children. Indeed, fathers themselves report being concerned about whether and how their new families can influence child-support awards (OCSE, 1996). If a primary goal of child-support policy is to ensure compliance, our findings would suggest that policies need to explicitly resolve the issue of award modification when fathers have new children. Of course, this issue is a difficult one to resolve, because it engages the question of which children should take precedence (e.g., Takas, 1991).

There are several limitations of our work. An obvious one is that our sample is quite small. Despite this shortcoming, our findings are robust to alternative specifications of the model, increasing our confidence in the findings. Nonetheless, our study ought to be replicated on larger samples when appropriate data are available, allowing for evaluations of differences in fathering for racialethnic and socioeconomic groups. Second, our data do not allow us to assess nonresident fathers' motivations for adjusting their child-support payments. Thus, for example, we cannot discern whether fathers feel an erosion in their commitment to their nonresident children with the arrival of a new child, whether they are responding to the financial constraints they face when they begin supporting another family, or whether they are reacting to some other set of factors. It is critical to build upon our analyses and existing qualitative work (e.g., Arendell, 1995) by empirically evaluating the reasons for fathers' decisions to modify their financial support to nonresidential children.
Third, we lack information about complex family situations. Our data only allow us to examine child-support payments to a focal child and his or her coresident siblings; some fathers have more than one set of biological children living outside their households. Fourth, other changes in fathers' and mothers' circumstance may create shifts in child-support payments. Our focus here is on testing a specific hypothesis about new children. A more rich data source should be employed to examine the influence of other factors.

Finally, our data very likely underreport nonresidential fatherhood. An inherent problem in this project is the selectivity based on unobserved characteristics of nonresident fathers. Currently, however, no national data set can make the claim of having a representative sample of nonresidential fathers. Although innovative efforts have been made to make adjustments via indirect estimation methods (e.g., Garfinkel, McLanahan, \& Hanson, 1998; Sorensen, 1997), these still are not ideal, and better sampling and data on fathers have become top research priorities (National Institute for Child and Health Development, 1996).

Nonetheless, our work is unique in being, to our knowledge, the first to empirically evaluate the effects of resident children, whether step or biological, on economic investments in nonresidential children. Despite the small sample size, we believe three broad implications of our study deserve special emphasis. First, future efforts aimed at understanding the nature of nonresident fatherchild ties, or fatherhood more generally, ought to widen their scope to incorporate both resident and nonresident offspring. Second, fathers in this sample often maintain financial ties to their children and in some cases increase their investments in nonresident children, further efforts should be employed to identify the mechanisms under which fathers maintain economic investments in their nonresident children. The third implication emerges from our finding that fathers' financial support for nonresident children appears to be conditional on their future fertility. Ultimately, this is a pattern that probably does not bode well for children's well-being in the United States, particularly given a societal context of increasing nonmarital fertility and union instability. Researchers should continue to pursue work on fathering as efforts to encourage father involvement are continually emerging and may result in new fathering dynamics.

\section{Note}

An earlier version of this paper was presented at the annual meeting of the Population Association of Amer- 
ica, March 1997 in Washington, DC. We thank participants at the Family Studies Seminar at the Survey Research Center of the University of Michigan, Yu Xie, Judith A. Seltzer, Alfred DeMaris, and Daniel D. Wiegmann for constructive suggestions. We are also grateful to Susan Stewart for excellent research assistance. Computer services were provided by Bowling Green State University. This research was supported by grants HD34391 and HD34392 from the National Institute of Child and Health Development.

\section{REFERENCES}

Adritti, J., \& Kelly, M. (1994). Fathers perspectives of their coparental relationships postdivorce. Family Relations, 43, 61-67.

Ahrons, C. (1983). Predictors of paternal involvement post-divorce: Mothers' and fathers' perceptions. Journal of Divorce, 6, 55-69.

Arendell, T. (1995). Fathers and divorce. Thousand Oaks, CA: Sage.

Becker, G. S. (1981). A treatise on the family. Cambridge, MA: Harvard University Press.

Braver, S., Fitzpatrick, P., \& Bay, C. (1991). Noncustodial parent's report of child support payments. Family Relations, 40, 180-185.

Bumpass, L. L., \& Sweet, J. A. (1989a). Children's experiences in single-parent families: Implications of cohabitation and marital transitions. Family Planning Perspectives, 21, 256-260.

Bumpass, L., \& Sweet, J. (1989b). National estimates of cohabitation. Demography, 26, 615-626.

Cherlin, A. J. (1978). Remarriage as an incomplete institution. American Journal of Sociology, 84, 634650.

Cherlin, A. J., Griffith, J., \& McCarthy, J. (1983). A note on maritally-disrupted men's reports of child support in the June 1980 Current Population Survey. Demography, 20, 385-389.

Clingempeel, W. G., Coylar, J. J., \& Hetherington, E. M. (1994). Toward a cognitive dissonance conceptualization of stepchildren and biological children loyalty conflicts. In K. Pasley \& M. Ihinger-Tallman (Eds.), Stepparenting: Issues in theory, research, and practice. Westport, CT: Greenwood Press.

Finkel, S. (1995). Causal analysis with panel data. Newbury Park: Sage Publications.

Furstenberg, F. F. (1988). Marital disruptions, child custody, and visitation. In A. Kahn \& S. Kammerman (Eds.), Child support (pp. 277-305). Beverly Hills, CA: Sage.

Furstenberg, F. F. (1995). Changing roles of fathers. In P. L. Chase-Lansdale \& J. Brooks-Gunn (Eds.), Escape from poverty: What makes a difference for children? (pp. 189-210). Cambridge: Cambridge University Press.

Furstenberg, F. F., Nord, C. W., Peterson, J., \& Zill, N. (1983). The life course of children of divorce: Marital disruption and parental contact. American Sociological Review, 48, 656-668.

Furstenberg, F. F., \& Spanier, G. B. (1984). Recycling the family: Remarriage after divorce. Beverly Hills, CA: Sage.

Furstenberg, F. F., \& Nord, C. W. (1985). Parenting apart: Patterns of childrearing after marital disruption. Journal of Marriage and the Family, 47, 893-904.
Furstenberg, F. F., \& Cherlin, A. (1991). Divided families: What happens to children when parents part. Cambridge, MA: Harvard University Press.

Furstenberg, F. F., \& Harris, K. (1992). The disappearing American father? Divorce and the waning significance of biological fatherhood. In S. South \& S. Tolnay (Eds.), The Changing American Family (pp. 197223). Boulder, CO: Westview Press.

Garfinkel, I., McLanahan, S. S., \& Hanson, T. L. (1998) A patchwork portrait of nonresident fathers. In I. Garfinkel, S. McLanahan, D. Meyer, \& J. Seltzer (Eds.), Fathers under fire (p. 31-60). New York: Russell Sage Foundation.

Heckman, J. (1979). Sample selection bias as a specification error. Econometrica, 47, 153-161.

Hill, M. (1992). The role of economic resources and remarriage in financial assistance for children of divorce. Journal of Family Issues, 13, 158-178.

Ihinger-Tallman, M., \& Pasley, K. (1987). Remarriage. Newbury Park, CA: Sage.

Kessler, R., \& Greenberg, D. (1981). Linear panel analysis. New York: Academic Press.

King, V. (1994). Nonresident father involvement and child well-being: Can dads make a difference? Journal of Family Issues, 15, 78-96.

Knox, V. W., \& Bane, M. J. (1994). Child support and schooling. In I. Garfinkel, S. McLanahan, \& P. Robins (Eds.), Child support and child well-being (pp. 285316). Washington, DC: Urban Institute.

Lin, I. F., \& Schaeffer, N. C. (1995). Using survey participants to estimate the impact of nonparticipation. Public Opinion Quarterly, 59, 236-258.

McLanahan, S. S., Seltzer, J., Hanson, T., \& Thomson, E. (1994). Child support enforcement and child wellbeing: Greater security or greater conflict? In I. Garfinkel, S. McLanahan, \& P. Robins (Eds.), Child support and child well-being (pp. 239-256). Washington, DC: Urban Institute.

Marsiglio, W. (1992). Stepfathers with minor children living at home. Journal of Family Issues, 13, 195214.

Meyer, D. (1998). The effect of child support on the economic status of nonresident fathers. In I. Garfinkel, S. McLanahan, D. Meyer, \& J. Seltzer (Eds.), Fathers under fire (p. 67-93). New York: Russell Sage Foundation.

Mott, F. (1990). When is father really gone? Paternalchild contract in father-absent homes. Demography, 27, 499-517.

National Institute for Child and Health Development. (1996, October). Conference on Father Involvement, Bethesda, MD.

Norton, A., \& Miller, L. (1992). Marriage, divorce, and remarriage in the 1990's. Washington, DC: U.S. Bureau of the Census.

Office of Child Support Enforcement. (1996). Evaluation of child support guidelines. Washington, DC.

Paasch, K. M., \& Teachman, J. D. (1993). Gender of children and receipt of assistance from absent parents. Journal of Family Issues, 12, 450-466.

Peters, H. E., Argys, L. M., Maccoby, E. E. \& Mnookin, R. H. (1993). Enforcing divorce settlements: Evidence from child support compliance and award modifications. Demography, 30, 719-735.

Schaeffer, N., Seltzer, J., \& Kalwitter, M. (1991). Estimating nonresponse and response bias: Resident and 
nonresident parents' reports about child support. Sociological Methods and Research, 20, 30-59.

Seltzer, J. A. (1991). Relationships between fathers and children who live apart: The father's role after separation. Journal of Marriage and the Family, 53, 79101.

Seltzer, J. A. (1994). Consequences of marital dissolution for children. Annual Review of Sociology, 20, 235-266.

Seltzer, J. A., \& Bianchi, S. M. (1988). Children's contact with absent parents. Journal of Marriage and the Family, 50, 663-677.

Seltzer, J. A., \& Brandreth, Y. (1994). What fathers say about involvement with children after separation. Journal of Family Issues, 15, 49-77.

Seltzer, J. A., McLanahan, S., \& Hanson, T. L. (1995). Will child support enforcement increase father-child contact and parental conflict after separation? In I. Garfinkel, S. McLanahan, D. Meyer, \& J. Seltzer (Eds.), Fathers under fire (pp. 157-190). New York: Russell Sage Foundation.

Smock, P., \& Manning, W. (1997). Nonresidential parents' economic ties to children: New evidence from the PSID. Journal of Marriage and the Family, 59, 798-808.

Sonenstein, F., \& Calhoun, C. 1990 Determinants of child support: A pilot survey of absent parents. Contemporary Policy Issues, 8, 75-94.

Sorensen, E. (1997). A national profile of nonresident fathers and their ability to pay child support. Journal of Marriage and the Family, 59, 585-191.

Sweet, J. A., Bumpass, L., \& Call, V. (1988). The design and content of the National Survey of Families and Households. NSFH Working Paper 1. Madison, WI. Center for Demography and Ecology, University of Wisconsin-Madison.

Takas, M. (1991). The treatment of multiple family cases under state child support guidelines. Washington, DC: U.S. Department of Health and Human Services.

Teachman, J. D. (1991). Who pays? Receipt of child support in the United States. Journal of Marriage and the Family, 53, 759-772.

Trivers, R. L. (1974). Parent-offspring conflict. American Zoologist, 11, 249-264.

U.S. Bureau of the Census. (1993). Child support for custodial mothers and fathers: 1991. Current Population Reports, P-60, No. 186. Washington DC: U.S. Government Printing Office.

Veum, J. R. (1993). The relationship between child support and visitation: Evidence from longitudinal data. Social Science Research, 22, 229-244.

Weiss, Y., \& Willis, R. J. (1985). Children as collective goods and divorce settlements. Journal of Labor Economics, 3, 268-292.

Zill, N. (1996). Noncustodial parents' participation in their children's lives: Evidence from the survey of income and program participation. Washington DC: U.S. Department of Health and Human Services.

APPENDIX

Probit and Tobit Effects for Sample Selection and Monthly Amount of Child Support Paid

\begin{tabular}{|c|c|c|c|}
\hline Variable & $\begin{array}{l}\text { Final Analytical } \\
\text { Sample, } \\
\text { Probit Coefficients }\end{array}$ & & $\begin{array}{l}\text { Log Monthly Child } \\
\text { Support, } \\
\text { Tobit Coefficients }\end{array}$ \\
\hline Family background intact & -0.02 & & - \\
\hline \multicolumn{4}{|l|}{ Mother's education } \\
\hline $\begin{array}{r}<12 \text { years } \\
12 \text { years } \\
>12 \text { years }\end{array}$ & $\begin{array}{c}-0.08 \\
\overline{0.39}\end{array}$ & & $\begin{array}{l}- \\
- \\
-\end{array}$ \\
\hline Employed full-time & $0.40 * *$ & & - \\
\hline \multicolumn{4}{|l|}{ Number of new coresident children } \\
\hline $\begin{array}{l}\text { Biological children: births } \\
\text { Biological children: move in } \\
\text { Stepchildren }\end{array}$ & $\begin{array}{l}- \\
-\end{array}$ & & $\begin{array}{l}-0.89 * * \\
0.30 \\
0.05\end{array}$ \\
\hline \multicolumn{4}{|l|}{ Wave 1 number of coresident children } \\
\hline $\begin{array}{l}\text { Biological children } \\
\text { Stepchildren }\end{array}$ & - & & $\begin{array}{l}-0.26 \\
-0.26\end{array}$ \\
\hline $\begin{array}{l}\text { Child support paid Wave } 1 \\
\text { Distance (in increments of } 100 \text { miles) } \\
\text { Wave } 1 \text { number of siblings } \\
\text { Wave } 2 \text { number of siblings }\end{array}$ & $\begin{array}{l}- \\
-\end{array}$ & & $\begin{aligned} & 0.74 * * \\
&-0.03 * * \\
&-0.19 \\
& 0.67\end{aligned}$ \\
\hline $\begin{array}{l}\text { rho } \\
n \\
\text { Log likelihood }\end{array}$ & 298 & $\begin{array}{r}0.09 \\
-461.1\end{array}$ & 133 \\
\hline
\end{tabular}

$* p \leq .05 . * * p \leq .01$

Source: National Survey of Families and Households, Waves 1 and 2. 